Tőke, Lilla. "The Outsider Within: Béla Tarr and Hungarian National Cinema." Hungarian Cultural Studies. eJournal of the American Hungarian Educators Association, Volume 9 (2016): http://ahea.pitt.edu DOI:

\title{
The Outsider Within: Béla Tarr and Hungarian National Cinema
}

\section{Lilla Tőke}

Abstract: Béla Tarr is probably the most paradoxical figure in contemporary Hungarian cinema. His artistic trajectory shows a movement from documentary style realism (Family Nest, 1979) towards more modernist cinematic practices (Satan's Tango, 1994, Werckmeister Harmonies, 2000, and The Man from London, 2007). A major celebrity in the global film culture that prides itself in being transnational, international, and in crossing linguistic and ethnic boundaries, Tarr has consistently found himself on the fringes of the Hungarian cultural and political establishment. In this study Töke considers Tarr's films and public persona as catalysts in the debates about what constitutes "Hungarian cinema" in a globalizing world from the 1970s until today.

Keywords: Béla Tarr, national cinema, Hungarian cinema, minor cinema, film politics

Biography: Lilla Töke is Assistant Professor of English at CUNY, LaGuardia Community College. She obtained her PhD from Stony Brook University in Comparative Literary and Cultural Studies. She also has an MPhil degree in Gender Studies from the Central European University, Budapest. Her research interests revolve around Eastern European cinema, transnationalism and media studies, as well as feminist theory.

There was a lot of shit things in the cinema, a lot of lies. We were coming with some fresh new, true, real things.

Béla Tarr, 1981

The renowned film critic, Jonathan Rosenbaum (1996), in a lengthy blog entry entitled "A Place in the Pantheon," praises Béla Tarr both in terms of his complex cinematography and the philosophical questions his films raise and claims that, "the breadth of [Tarr's] canvas suits the magnitude of what he has to say." The title of the blog clearly suggests that Rosenbaum considers Tarr as one of the living "Gods" of European filmmaking and the global art film festival scene. Bloggers, critics, and academics seem to agree as they continue to attend special screenings, get captivated by, and write at length about Tarr's epic black and white movies, which progress at an excruciatingly slow pace and have minimalist narratives. Susan Sontag and Gus van Sant are just two of many critics who admire Tarr and describe him as someone whose films have had great influence on their thinking as well as cinema making (Williams 2003, Jones 2008). In an interview, Sontag called Sátántangó ['Satan's Tango,' 1994], specifically, one of her all-time favorite movies, stating that she would be "glad to see it every year for the rest of [her] life" (Chan 2001). 
Tőke, Lilla. “The Outsider Within: Béla Tarr and Hungarian National Cinema.” Hungarian Cultural Studies. eJournal of the American Hungarian Educators Association, Volume 9 (2016): http://ahea.pitt.edu DOI:

Tarr's films have circulated and won numerous awards at major art film festivals around the globe and he has been widely recognized as the Hungarian film director par excellence abroad. However, very few viewers or critics outside Hungary are aware of two important factors. First of all, Tarr's career is very closely tied to the cultural politics of Hungary from the nineteen seventies to the present, and, second, this relationship is much more controversial than most international viewers and critics realize. Such an important oversight relating to the political background of Tarr's work is due to the fact that, as Bill Nichols (2013: 34) astutely observes, "the international film festival circuit [often] does not tell origin stories, relying on a timeless zone of tribal culture or Third Cinemas as back up for the emergence of a modernist cinema in the West." It is this "origin story" that I hope to reconstruct - the story that lies behind the enthusiastic celebration of Tarr's films in the global art film festival culture. Béla Tarr's story is uniquely powerful in revealing the intricate flow of cinema between a globalized visual culture and national film practices. Further, Tarr's story also exposes the ways in which individual artists navigate the often competitive and contentious relationship between national and global cinemas. In the following, I intend to examine Tarr's films and public persona as catalysts in the debates about the direction of "Hungarian cinema" in a globalizing world.

Critics and cinephiles worldwide recognize Tarr as one of the very few, if not the only, Eastern European filmmakers today with a lasting legacy. Besides winning numerous awards, his films have made it onto several "best of world cinema" lists, for instance The Guardian's "Forty Best Film Directors in the World" and also "The Best Non-English Language Films" created by film critic and blogger, Edward Copeland. In contrast, while it is true that Tarr's work has been enthusiastically received by a small group of Hungarian academics and intellectuals, for most of his career Tarr's films were either ignored by domestic film audiences or sparked heated critical controversies. For example, the list of "Twelve Best Hungarian Films" [Új Budapesti tizenkettó] composed by Hungarian filmmakers and critics in 2000 did not contain any work by Tarr. Moreover, he was advised on several occasions to quit making films because he was just an amateur, "a wannabe" (Kovács 2013: 10) and unlike other internationally recognized Hungarian filmmakers, he was never invited to teach at the Hungarian Film Academy even though he taught repeatedly at the DFFB, Germany's most prestigious film school. One of the few committed Tarr scholars and the artist's close friend, András Bálint Kovács (2013: 173) correctly points out the exiting discrepancy between Tarr's reception in Hungary and in global and domestic film circles. However, Kovács stops short of giving a plausible explanation for the inconsistency and what he admits is Tarr's contentious and peripheral position in Hungarian cinema.

Starting with his very first movie, a documentary about Gypsy shipyard workers that he had made as a teenager, Tarr's films have been regularly deemed "inappropriate" and "unworthy" by Communist Party elites as well as, more recently, by the right-leaning FIDESZ government and its cultural ambassadors. The first Tarr movie to receive critical acclaim, Kárhozat ['Damnation,' 1988] won prestigious awards at Cannes and Bergamo, but only received the prize of the international jury at the thirty-second Hungarian National Film Week alongside harsh domestic reviews and it was essentially rejected by the domestic jury (Kovács 2013: 10). Although Tarr's second internationally celebrated film, Werckmeister harmóniák ['Werckmeister Harmonies,' 2001] did receive the Grand Prize at the Hungarian Film Week in 2001, it, too, became the center of intense critical controversy when some journalists condemned it for its dark, depressing world, lack of realism, and defamiliarizing effects (Jánossy 2001). 
Tőke, Lilla. "The Outsider Within: Béla Tarr and Hungarian National Cinema." Hungarian Cultural Studies. eJournal of the American Hungarian Educators Association, Volume 9 (2016): http://ahea.pitt.edu DOI:

Probably the most notorious example of Tarr's struggle with domestic financing, exhibition, and reception practices relates to his best-known, seven-hour long, Sátántangó. The project was conceived in 1985 but was put on hold until 1993 because Tarr could not secure funding for the film from the major studios due to his outsider position and also due to strict political censorship. When it was finally screened in1993, the film received the "Caligari" award at the Berlin International Film Festival and the "Age d'Or" prize at the Brussels International Film Festival. Nevertheless, the organizers of the twenty-fifth Hungarian National Film Week in 1994 decided to screen Sátántangó in a tiny movie theater and were thoroughly surprised to see hundreds of viewers show up to watch this epic length movie. In the end, Sátántangó was given a "special prize" at the event, probably due to its emerging cult status abroad and the enthusiastic reception by a small circle of Hungarian critics and cinephiles.

It took almost twenty-seven years for Tarr to gain recognition by the Hungarian political and professional establishment. Ágnes Hranitzy, Tarr's wife and creative partner explains the generally dismissive attitude to his films in Hungary when, in an interview about the making of Öszi Almanach ['Almanac of Fall,' 1884] and Kárhozat she states that, "it was crystal clear that the hair and make-up artist did not consider him [a professional]. They didn't say it, but that was the general atmosphere amongst the crew: 'here is this wannabe trying to make a splash.'" [Teljesen világos volt, hogy a fodrász vagy a sminkes nem tartotta annak. Ezt nem mondták ki, de olyan volt a hangulat; 'itt ugrál valami pali'] (Kovács 1994) [All translations from Hungarian are my own]. Much later, in 2002, Tarr was finally nominated for the highest national decoration, the Kossuth-dij ['Kossuth Award']. However, even then the conservative FIDESZ government rejected the nomination and Tarr had to wait yet another year until a new government came to power and finally handed him the honor (Kovács 2013: 173). In 2010, Tarr assumed his most influential professional position as elected president of the Hungarian Filmmakers' Association, but — as we shall see below - his stormy tenure came to a quick end two years later.

\section{Tarr's Emergence in the Context of Hungarian Political and Media History}

In order to understand Tarr's controversial position in Hungary's "politics of recognition" (Taylor 1997: 98), first we need to briefly look at Hungarian media history. In the late 1960s, the Hungarian government worked hard to start a new chapter in its national and international politics. As Hungary opened politically and culturally, Western film audiences were keen to peek behind the Iron Curtain and to see "communist art" for the first time. Moreover, these audiences saw in the politically engaged Eastern European New Wave a validation of their own antitotalitarian, anti-communist discourses. Such representatives of the Hungarian New Wave as Miklós Jancsó and István Szabó alongside a new generation of filmmakers (in particular, Zoltán Fábri, István Gaál, András Kovács, and Péter Bacsó) signaled a move away from the failed project of socialist realism and played a key role in Hungary's cultural and political thaw. Jancsó's sudden rise to celebrity status both at home and internationally is particularly pertinent since his fictional world, narrative pace, and aesthetic style are very close to Tarr's. The filmmakers of the Hungarian New Wave quickly became cherished voices of critique against Soviet imperialism, socialist totalitarianism and messengers of universal humanism and pacifism at home and abroad. Their metaphoric representations of suffering Eastern Europeans attracted Western audiences because they validated the idea that Soviet presence in Eastern Europe was tyrannical and brutal and that the communist system was inherently dehumanizing and exploitative. At the same time, the political symbolism of the Hungarian New Wave also 
Tőke, Lilla. “The Outsider Within: Béla Tarr and Hungarian National Cinema.” Hungarian Cultural Studies. eJournal of the American Hungarian Educators Association, Volume 9 (2016): http://ahea.pitt.edu DOI:

appealed to domestic audiences, who saw themselves as targets of Soviet imperialism and of the oppressive political regime.

Unfortunately for Tarr, he started making films in the 1970s when Hungary entered a new phase of political reconciliation referred to as gulyás ['goulash'] communism - an era characterized by political consolidation that implied a tacit agreement between the state and its citizens, whereby citizens could establish private companies and accumulate private capital in exchange for a complete withdrawal from political life. As Hungary's diplomatic interactions with the West strengthened and international relations started to normalize, more and more Hungarians travelled to the West, enjoyed Western goods and turned away from political radicalism. In this new phase of political and economic consolidation, the Hungarian political establishment did not need to actively promote openness and modernity by supporting politically and aesthetically radical projects such as the Hungarian New Wave.

In addition to the significant political change and the noticeable wavering of enthusiasm for all New Wave cinemas, Hungarian filmmakers such as Tarr, who began their careers in the 1970s, also had to face challenges due to the increasing access to television and VHS technology, which had dramatic effects on audience viewing habits and Hungarian mass culture. In 1960 only four Eastern European countries produced altogether six hundred thousand television sets. By 1980 the countries in the region manufactured over three million units total (Berend 1996: 192). This five-fold increase in the number of household television units in Eastern Europe is a good indication of the changing nature of mass entertainment. First of all, the number of cinemagoers substantially decreased as the immediate, all-day programming of television offered a more convenient and more consistent form of entertainment. In addition, the increasingly common encounters with Western lifestyle also accelerated the popularity of Hollywood style genre films and television series produced in the West as well as domestically, which provided a perfect escape from the stifling realization that there was "no end in sight" for the one-party state socialism. These new forms of mass entertainment starting from the 1970s brought about a major paradigmatic change in the role of art film in the communist Eastern Europe, which lost its mass appeal as a political tool. Tarr began his career precisely at this difficult time for radical cinema when Hungarian art film was struggling to find its cultural position as well as audience.

\section{Tarr's Films in the Context of the Politics of Small Nation Cinema}

Another important factor that contributed to Tarr's marginalization in Hungarian national film industry relates to the status of Hungarian film as a small nation cinema. Mette Hjort's seminal book (2005) on the Danish Dogme describes "minor cinema" or "small nation cinema" as cinema made from a certain position of disadvantage in the regimes of cultural power (2005: ix). Minor cinema, as Hjort sees it, is more likely to amplify the self-celebratory myths of an imaginary community while also taking part in "the politics of recognition"- the desire to ensure that the value of national culture is "registered to the greatest extent possible both within and beyond the relevant national borders" (Hjort 2005: xi).

Hjort (2007:14) readily recognizes that minor cinemas face particular challenges in increasingly globalized cultural and economic networks, which often "serve to erode the cohesion of nations," however she seeks to demonstrate that regional, transnational, and global flows of culture can rejuvenate national cinemas creating opportunities of "unprecedented international visibility" (2007:18). She considers the emergence of New Danish Cinema as an illustration that small nations can react to and take advantage of the transformative effects of 
Tőke, Lilla. “The Outsider Within: Béla Tarr and Hungarian National Cinema.” Hungarian Cultural Studies. eJournal of the American Hungarian Educators Association, Volume 9 (2016): http://ahea.pitt.edu DOI:

globalization in ways that ultimately generate political and cultural capital inside and outside the borders of the nation state. Unfortunately, Hungary's film politics shows a much less optimistic and murkier picture about the relationship between national and global cinema than its Danish counterpart.

Hungarian cinema definitely displays the major perils of a small nation cinema: the country is too small to sustain a commercially-based, indigenous film industry; linguistic barriers make it difficult to expand the Hungarian film market through export and international distribution; and finally, the ongoing influx and dominant presence of Hollywood films clearly impacts the aesthetic and financial characteristics of the domestic film industry (Hjort 2001: 20). Hungarian films have needed and enjoyed substantial state sponsorship since 1919, when Hungary became the first nation to fully nationalize its film production system. While it is true that state sponsorship has long assumed the role of major cultural facilitator in Hungary's national "politics of recognition," the country's strive towards domestic and global cultural visibility is wrought with contradiction and confusion. Due to its financial dependence throughout its history, Hungarian cinema has been subjected to national politics and state censorship. John Cunningham (2004: 69) succinctly describes, for instance, the Byzantine everchanging bureaucratic system between 1945 and 1990, when many different departments exercised tight yet unpredictable control over the creative, production, and distribution processes.

Since the state has been the primary source of support for the Hungarian film industry, the grip of political control has put considerable pressure on Hungarian film makers, although at certain times, such as the 1960s and late 1980s, it did allow filmmakers "greater control over their choice of project and the financing" (Cunningham 2004: 116). In Hungary's system of state control, Tarr belonged to what he describes as the "tornacipös kategória" (Kovács 1994), the category of "sneaker-wearing" artists, who made their movies with very little financial support and were not considered serious artists because they did not follow the well-established, institutional path to professional film making. Indeed, Tarr has never shown any interest in working within the confines of the politically over-determined financial and production system.

Tarr's example demonstrates that "the politics of recognition" often seems to be in opposition to nationalist ideologies and cultural projects that validate certain heroic collective memories and narratives. What global audiences today think of as "Hungarian cinema," is in fact more often than not marginal(ized) in the country's own film culture. Although Hjort's analysis of Danish Dogme remains overall optimistic about the potentials of national culture to transpire into the transnational and global sphere, yet, even she expresses concern about the close involvement of state institutions in filmmaking. Hjort observes that "the link between minor cinema and small-nation status imposes a certain task on the film industry - that of contributing to an ever urgent project of national memory and validation," which is exactly the case in Hungary (2005: 116). To go even further, in small nations, global recognition can induce a reaction of resistance and displeasure because of a "siege mentality" associated with concerns about "political survival and national viability" (Ganesan 2005: 1-2). Such resistance, due to Hungarians' siege mentality, can explain why, despite the fact that Hungary's "politics of recognition" has clearly benefitted from Tarr's artistic reputation across the globe, his artistic value at home has been minimally acknowledged and rarely rewarded.

It is important to note here that the paradox of Tarr's artistic recognition is not unique to Hungary but that other minor cinemas, such as the New Romanian Cinema, which is far from popular with the majority of Romanian audiences, show similar discrepancies between what is 
Tőke, Lilla. “The Outsider Within: Béla Tarr and Hungarian National Cinema.” Hungarian Cultural Studies. eJournal of the American Hungarian Educators Association, Volume 9 (2016): http://ahea.pitt.edu DOI:

popular locally and what is cherished by global art film audiences. The discrepancy, to an extent, can be explained by a fundamental difference in style between art films and mainstream cinema, where the latter clearly enjoys the support of mass audiences. However, the hostility that Tarr and his work have met across various political configurations and film industry systems since the nineteen seventies goes beyond Hungarian viewers' stylistic preferences. Tarr's persona as well as his work have been systematically disregarded, if not straightforwardly ignored, because they are too uncomfortable, too defiant, and too provocative for a small nation that is characterized by state-run and ideologically determined sponsorship and which tends to favor "patriotic styles of filmmaking" (Hjort 2005: 114). Tarr has neither desired nor has been perceived to fulfill a "constructive" role in Hungary's nation-building project.

\section{The Outsider Within: Tarr as a "Minor" Artist}

Tarr's marginal position in Hungarian cinema, therefore, illustrates the struggle that many filmmakers face who do not fit into the limiting realities of small nation cinemas and their "politics of recognition." This position can be described best as "minor" in the sense that Gilles Deleuze and Felix Guattari (1983) originally defined the term in their article, "What Is Minor Literature?" relying on Franz Kafka's work as an example. Minor cinema, just like minor literature, pushes the viewer to see the world differently, to experience it in radically new ways that goes beyond transparent representation, in order to disclose the exploitation, humiliation, and violence inherent in all political systems. Tarr's cultural vantage point is similar to Kafka's who, almost a century ago, was writing in German as a Jew living in the primarily Czech speaking Prague. Just like Kafka, Tarr is "a sort of stranger" (Deleuze 1983: 26) in Hungarian cinema and his films show marginality to be "a general human condition that can be seen especially clearly from certain geopolitical angles" (Kovács 1988) whether that is the crumbling Austro-Hungarian empire, the disintegrating socialist system, or the growingly nationalist contemporary Hungary.

More than simply a stranger, Tarr has — willingly — occupied the position of the "agent provocateur" in Hungarian culture and politics. As a teenager he ran into trouble with party officials because of his affiliation to a radical, domestic Maoist group and because he recorded several interviews with shipyard workers for his first film, interviews that disclosed the depressing everyday reality in 1970s' Hungary. As a consequence, Tarr was denied entrance to any university after graduating from secondary school. However, while working as a physical laborer, he continued to make (prize-winning) small budget films and eventually was accepted to work at the Béla Balázs Film Studio, where at the age of twenty-two, he became one of the youngest ever Hungarian filmmakers to release a full-length feature, Családi tüzfészek ['Family's Nest,' 1979]. Still, due to the state-dependent, hierarchical, and nepotistic nature of the Hungarian film industry, which is characteristic of small nation cinemas in general, Tarr was not allowed near any major film production at the BBFS.

After several successful movies made independently, Tarr was eventually admitted to Szinház és Film Müvészeti Egyetem ['The National Film Academy'], where he remained an outsider as he did not bother to attend classes and was instead making the movies he always wanted to make. While at the film academy, Tarr finished Panelkapcsolat ['The Prefab People,' 1982] and also Macbeth (1982), which was his graduation piece. After the academy, he did not join any of the already existing studios, instead in collaboration with a few friends he founded Társulás ['Collective'], a new film studio intended to make semi-documentary, "cinéma véritê" 
Tőke, Lilla. “The Outsider Within: Béla Tarr and Hungarian National Cinema.” Hungarian Cultural Studies. eJournal of the American Hungarian Educators Association, Volume 9 (2016): http://ahea.pitt.edu DOI:

style movies. This project was short-lived, however, because it was a source of contempt for the other, more established film studios reluctant to share their already-limited state funding.

Since Tarr was never a member of any major national film studio, he learned to function effectively as his own executive producer and to find funding largely outside of the official state financing system. The continuous fight for survival finally prompted Tarr to establish his own production company in 2003 and named it TT Filmmühely ['TT Filmworkshop']. Originally intended to finance $A$ londoni férfi ['The Man from London'], the company quickly became a crucial source of support for many young and struggling Hungarian filmmakers (including Benedek Fliegauf, Simon Szabó, Ágnes Kocsis, and György Pálfi), who Tarr described as "the team of the heartbroken" [összetört szivek csapata] (Bori 2007). The artists sponsored by TT Filmmühely were in a similarly contemptuous position as Tarr, as they, too, were also struggling on the fringes of Hungarian cinema because their projects had no commercial appeal or they refused to compromise their aesthetic vision.

In 2008 when the organizers of the National Film Week scheduled A londoni férfi (2007) to be released in a freshly built multiplex, a new location that was supposed to demonstrate that Hungarian cinema is finally in synch with Western standards, Tarr protested and, in another act of defiance, demanded that his film be moved to a small art cinema. His reputation as a "difficult person to work with" followed Tarr one year later when he withdrew his candidacy for the inaugural leadership position of the future Magyar Nemzeti Filmalap ['Hungarian National Film Fund'] as it became clear that neither government agencies nor major industry leaders supported his radical ideas of how to run the foundation. Yet, his support by fellow filmmakers was confirmed in 2010 when he was elected president of the Magyar Filmmüvészek Szövetsége (MFSZ) ['Hungarian Filmmakers Association'], which gave him an influential voice in representing the interests of Hungarian moving image artists. Tarr made it clear from the beginning that, under his leadership, the trade union would pursue an aggressive agenda to defend the rights of film artists against tightening economic and political control. The Association went on to organize the infamous "fapados" ['economy class'] forty-third Hungarian Film Week under impossible financial conditions and without any support from the Hungarian government. Despite the lack of media publicity or financial awards, the festival turned out to be a huge success, thanks to Tarr's determination, his international recognition, as well as to the hundreds of dedicated volunteers and film professionals.

In the same year, Hungary's prime minister, Viktor Orbán, appointed Andrew Vajna to the newly created position of state commissioner responsible for restructuring the national film industry. Vajna and his team quickly dissolved the indebted Magyar Mozgókép Közalapítvány (MMKA) ['Hungarian Moving Image Foundation'] and took over the leadership of the Magyar Nemzeti Filmalap, introducing new guidelines that placed emphasis on commercial considerations and removing the filmmakers from the decision-making process. Vajna's proposition was to "bring Hollywood to Hungary," by which he meant two things: first, that the Filmalap would give financial incentives for Hungarian versions of Hollywood-style genre movies that could presumably draw in domestic audiences. Second, the plan also included the aggressive promotion of the Hungarian film production infrastructure in the West as Hollywoodfriendly, high quality and low cost (ATVzrt 2013). As president of HFA, Tarr (2013a) repeatedly criticized Vajna's overhaul of the national film industry and claimed that it brought a "shift from the cultural to an economic imperative" (Hjort 2007: 9) excluding film makers themselves from any decision-making process. 
Tőke, Lilla. "The Outsider Within: Béla Tarr and Hungarian National Cinema." Hungarian Cultural Studies. eJournal of the American Hungarian Educators Association, Volume 9 (2016): http://ahea.pitt.edu DOI:

Tarr soon became the living proof of his own predictions as in 2011 the new industry set up essentially ended his tenure as President of the Hungarian Filmmakers' Association, which lost all its bargaining power and was reduced to a Facebook page and a minimalist webpage. In addition, Vajna's reforms also destroyed Tarr's production company, TT Filmmühely, which ceased all its operations in May 2012. For the first time in its Hungarian film history, the fortyfourth National Film Week in 2013 was cancelled due to lack of funding and lack of films to exhibit. In what can be considered as one of the grimmest periods of Hungarian film making, Tarr continued to voice the anger and frustration of many Hungarian filmmakers whose work was made impossible by the new government regulations. In an interview, he describes his mission as a necessary but hopeless battle explaining that, "The situation in Hungary is horrible and I feel that democracy is in danger. [...] Seven hundred filmmakers elected me to that position to represent our interests and keep Hungarian cinema alive, which is so difficult now. I'm doing my best, but I have to confess I have not had much success. We're fighting a losing battle. If people want to make films they have to compromise with the system" (Nesbitt 2013).

Tarr's nationally and internationally publicized criticism of the state of contemporary Hungarian film politics was met with a sarcastic reaction by Vajna who declared that "Béla Tarr is not part of the Hungarian film industry" [Tarr Béla már nem része a Magyar filmiparnak] (Tarr 2103b). While this statement on the surface seemed to refer to Tarr's earlier announcement that he stopped making films after A turinoi ló ['The Turin Horse,' 2012], the cynical trivialization of Tarr's artistic decision and the bitter exchange between the two (Csákvári 2014) discloses a sad irony. Right at the moment when due to his international recognition Tarr finally had became a core figure in the nation's film politics, his production company, and his elected position, he gave up making films altogether and was once again pushed to the side by those inside the "pigsty" (Kovács 1994), as in an interview he described to the inner circles of the Hungarian film industry.

Nevertheless, it is important to recognize that in spite of his presumed retirement from filmmaking Tarr continues to assert himself and his artistic philosophy in the global art cinema culture. Most recently, he established his own "film.factory" housed by The Sarajevo Film Academy in Serbia, essentially a film making workshop formed by a truly international faculty and student community that disregards traditional school curriculum and educational hierarchy as well as mainstream pedagogical practices. Jonathan Rosenbaum (2015) recognizes the irony in Tarr's decision, namely that while the establishment of the film.factory is the major step in his career as an artist, at the same time it is also a clear "break with his past as both a filmmaker and as a Hungarian [...], ending many long-term professional as well as personal relationships and effectively sending him into exile."

It is quite possible that Tarr's self-exclusion is partly a reaction to Hungary's growing sense of national(ist) defensiveness. The new film industry structure and financing system established by Vajna is a reflection of Hungarians increasingly contemptuous reaction to global art film and the kind of filmmaking that is universal in its scope and radical in its politics. Tarr's artistic philosophy, reflected in his films, offers a "humanist coloration of a great family of man" and celebrates "cross-cultural understanding" (Nichols 2013:30) in a way that falls completely outside the direction of contemporary Hungarian film politics characterized by growing skepticism towards multiculturalism and liberal humanism as well as by a strong economic imperative. Tarr's story, therefore, is a story of displacement and marginal artistic existence. The 
Tőke, Lilla. “The Outsider Within: Béla Tarr and Hungarian National Cinema.” Hungarian Cultural Studies. eJournal of the American Hungarian Educators Association, Volume 9 (2016): http://ahea.pitt.edu DOI:

kind of deterritorialized existence that he embodies also serves as the central focus of his films that defy easy definitions or classifications. I venture so far as to claim that Tarr's final act of self-silencing, his retreat from film making itself, can be understood as an act of purposeful deterritorialization and (self)marginalization.

Tarr's resistance to the recent, nationalist turn in Hungary's public discourse is completely in line with his view that the purpose of film making as well as film viewing is to critically engage with the world in a state of social, ontological, and even cosmic crisis. In an interview he states that,

At the beginning of my career, I had a lot of social anger. I just wanted to tell you how fucked up the society is. This was the beginning. Afterwards, I began to understand that the problems were not only social; they are deeper. I thought they were only ontological. It's so, so complicated, and when I understood more and more, when I went closer to the people... afterward, I could understand that the problems were not only ontological. They were cosmic. The whole fucked up world is over. That's what I had to understand, and that's why the style has moved. Once I went down, I kept going down (Kohn 2013).

Every landscape, every scene, and every character in Tarr's films is transpired by a quest for existential realism that turns into a provocation to see "the world as is, the shit for what it is" (Kovács 1998) disclosing a deep cosmic crisis but without metaphysical pessimism. The style of Tarr's films - including but not limited to long shots, slow camera movement, intense close ups, and black and white footage - contribute heavily to our discomfort witnessing human suffering, alienation, and self-subjugation.

In face of the cosmic darkness, Tarr's slow, contemplative, modernist films push the viewer towards a universal and ethical affirmation of humanism. An important aspect of this humanism is the "love" we develop for the characters, a sense of compassion that derives from being "one of them" (Kovács 2013:167). It is important to recognize that "love" in Tarr's interpretation lacks melodramatic associations and instead requires a depositioning of the self and a radicalization that confronts human misery and self-annihilation through empathy. Indeed, Tarr's films make viewers feel distraught to a degree that they refuse to accept that we are bound by a predetermined order and that "you know your place. That the cards have been dealt" $[A z$, hogy tudd a helyedet. Hogy le vannak osztva a lapok] (Kovács 2003). The films give voice to the silenced, the suppressed, and show the elementary need for human compassion. László Krasznahorkai, the writer whose books serve as the screenplay for most of Tarr's films, in an interview confirms that every Tarr film is essentially a provocation to rebel against social, political, or ideological constraints and to "look for positive answers in our moral outrage" [Minél eröteljesebben utasitja vissza valaki ezt a filmet egy morális alapállásról, annál inkább rá van kényszerítve, hogy saját magában keressen ehhez erkölcsi támpontokat] (Kovács 1998). As a minor artist, just like Kafka, Tarr questions self-serving and exclusivist identities such as the nation and instead calls on a collective that springs from the multiplicity of human experience and universal human compassion.

Tarr's films ask questions such as: what does it mean to be human? When do we stop acting as humans? What forces drive us to act in inhuman ways? When there is nothing left in the world, when we have lost everything and have been completely crushed, humiliated and 
Tőke, Lilla. "The Outsider Within: Béla Tarr and Hungarian National Cinema." Hungarian Cultural Studies. eJournal of the American Hungarian Educators Association, Volume 9 (2016): http://ahea.pitt.edu DOI:

exploited, how do we retain our humanity? His answer is that we remain humans by clinging onto each other and by recognizing in each of us that which is untouchable, repulsive, the abject. However, Tarr's insistence on human dignity is not so much in moral terms but, similar to the concepts and beliefs of Giorgio Agamben and Franz Kafka, it stems from the recognition that human solidarity is a bare, existential need for our survival. Tarr's entire artistic oeuvre in fact testifies to the existence of the outsider in all of us, in our utter isolation and displacement at the mercy of unforgiving social, economic and even physical conditions. Under these circumstances, it is human dignity as well as a relentless search for intimacy and connection, which demarcate our last, remaining sense of humanity.

In the end, Tarr's marginal position in Hungarian national cinema starts to make sense if understood in terms of the vision of a minor artist, whose work constantly grapples with how to represent the impossible, the abject, and also the absolute need for a human collectivity that is inclusive and universal. It is perhaps not all that surprising that Hungarian viewers as well as the ideological state apparatus hard at work to construct and maintain positive mythologies about the nation as a desirable and viable collective are quick to reject Béla Tarr's raw and painful realism engulfed in radical, modernist visual aesthetics. Tarr's work does not integrate into Hungary's small nation politics that strives to present itself through an exclusive picture of belonging and exceptionalism in the midst of a rapidly changing and unfamiliar outside world. National cinemas, especially if small, rarely tolerate provocateurs that destabilize and upset much of what they hold "dear." However, when in Hungary's history so much of the public discourse and cultural politics mandates that art service dominant state ideologies and perpetuate grandiose myths of national unity and perseverance, it is vital for Hungarians to have artistic voices such Tarr's who attempt to fashion different stories for us - stories about how to exist as strangers, as abject, as a minority, as minor.

\section{Works Cited}

ATVzrt. 2013. "Merre tovább magyar film?" ['Whither Hungarian Film?']. Online video clip. Youtube. Youtube, 3 May. https://www.youtube.com/watch?v=_oZgRQ3B5wI

Berend, T. Iván. 1996. Central and Eastern Europe, 1944-1993: Detour from the Periphery to the Periphery. Cambridge: Cambridge UP.

Bori, Erzsébet. 2003. "Torony az éjszakában: beszélgetés Tarr Bélával" ['Tower in the Night: Interview With Béla Tarr']. Filmvilág 8: 25-26. http://filmvilag.hu/xereses_frame.php?cikk_id=2301

— 2007. "Nehéz fiúk klubja: beszélgetés Tarr Bélával" ['The Club of the Heavyweight: Interview With Béla Tarr']. Filmvilág 4: 18-21. http://www.filmvilag.hu/xista_frame.php?cikk_id=1971

Chan, Evans, and Susan Sontag. 2001. "Against Postmodernism, etcetera: A Conversation with Susan Sontag." http://pmc.iath.virginia.edu/text-only/issue.901/12.1chan.txt

Csákvári, Géza. 2014. "Tarr Béla harca a Vajna-rendszerrel" ['Béla Tarr's Battle with the Vajna System']. Nol.hu. Mediaworks Print, April 16. http://nol.hu/kultura/vasarnapi-interju-tarr-belaval-londonban-kod-1450303

Cunningham, John. 2004. Hungarian Cinema: From Coffee House to Multiplex. London: Wallflower.

Deleuze, Gilles, Félix Guattari, and Robert Brinkley. 1983. "What is Minor Literature?" 
Tőke, Lilla. "The Outsider Within: Béla Tarr and Hungarian National Cinema." Hungarian Cultural Studies. eJournal of the American Hungarian Educators Association, Volume 9 (2016): http://ahea.pitt.edu DOI:

Mississippi Review 11/3: 11-13.

Gansean, Narayanan. 2005. Realism and Interdependence in Singapore's Foreign Policy. New York: Routledge.

Hjort, Mette, and Duncan J. Petrie. 2007. The Cinema of Small Nations. Bloomington: Indiana UP.

Hjort, Mette, and Ib Bondebjerg. 2001. The Danish Directors: Dialogues on a Contemporary National Cinema. Bristol, UK: Intellect.

Jánossy, György. 2001. "Werckmeister-vita: Tar(r)talom és Forma" ['Werckmesiter-Debate: Content and Form']. Magyar Narancs 38. http://magyarnarancs.hu/konyv/werckmeistervita_tarrtalom_es_forma-58178

Jones, Jenny. 2008. "Gus Van Sant in the Light of Béla Tarr.” Walkersart.org. Walker Arts Center. http://blogs.walkerart.org/filmvideo/2008/03/17/gus-van-sant-light-bela-tarr/

Kohn, Erik. 2012."An Interview With Béla Tarr: Why He Says The Turin Horse Is His Last Film." Indiwire.com. Penske Business Media. http://www.indiewire.com/2012/02/aninterview-with-bela-tarr-why-he-says-the-turin-horse-is-his-final-film-242518/

Kovács, András Bálint. 1994. "A falfelület is történet: beszélgetés Tarr Bélával és Hranitzky Ágnessel" ['Even Walls Tell Stories: Interview with Béla Tarr and Ágnes Hranitzky']. Filmvilág. 6: 10-13.

—. 1998. "Monológok a Kárhozatról” ['Monologues about Damnation']. Filmvilág 2: 16-19.

- 2013. The Cinema of Béla Tarr: The Circle Closes. New York: Columbia UP.

Kürti, László. 1998. "Hungary.” In Eastern Europe: Politics, Culture and Society Since 1939. Ed. Sabrina P. Ramet. Bloomington: Indiana UP: 71-93.

Nesbitt, Hue. 2013. “A Home for the Brave: Béla Tarr's Film Factory.” Dazed. December. http://www.dazeddigital.com/artsandculture/article/18014/1/a-home-for-the-brave-belatarr-s-film-factory

Nichols, Bill. 2013. "Global Image Consumption in the Age of Late Capitalism." In The Film Festivals Reader. Ed. Dina Iordanova. St Andrews: St Andrews Film Studies. 29-44.

Rosenbaum, J. 1996. "A Place in the Pantheon." Chicago Reader. May 9. http://www.chicagoreader.com/chicago/a-place-in-the-pantheon/Content?oid=890479

_ 2015. "A Personal Report on an Adventure Called film.factory." BFI. British Film Institute, August 7. http://www.bfi.org.uk/news-opinion/sight-soundmagazine/comment/personal-report-adventure-called-filmfactory

Tarr, Béla. 2013a. "Tarr Béla: nincs mit befüzni a vetítőgépbe" ['There is No Stock to Feed into the Camera']. Start Plusz. ATV.hu. ATV. February 4. http://www.atv.hu/egyeb/20130204_tarr_bela

—. 2013b. "Tarr: Több eleganciát vártam volna Andy Vajnától" [Tarr: I Would Have

Expected More Sophistication from Andy Vajna']. ATV.hu. ATV. February 3. http://www.atv.hu/belfold/20130202_tarr_bela_tobb_eleganciat_vartam_volna_andy_vaj natol

Taylor, Charles. 1997. "The Politics of Recognition." In New Contexts of Canadian Criticism. Eds. Ajay Heble, Donna Palmateer Pennee and J.R. Tim Struthers. Orchard Park, NY: Broadview: 98-131.

Williams, Richard. 2003. "Deep Waters." The Guardian. April 8. http://www.theguardian.com/film/2003/apr/19/artsfeatures 